\title{
Vapor transport and sublimation on Mullins Glacier, Antarctica
}

\author{
J. L. Lamp ${ }^{\mathrm{a} 1}$, D. R. Marchant ${ }^{\mathrm{a}}$
}

\begin{abstract}
We utilize an environmental chamber capable of recreating the extreme polar conditions of the McMurdo Dry Valleys (MDV) of Antarctica to investigate the sublimation rate of the Mullins Valley debris-covered glacier (hereafter Mullins Glacier), reportedly one of the oldest debris-covered alpine glaciers in the world. We measure ice loss via sublimation beneath sediment thicknesses ranging from 0 to $69 \mathrm{~mm}$; from this, we determine an effective diffusivity for Fickian vapor transport through Mullins till of $(5.2 \pm 0.5) \times 10^{-6} \mathrm{~m}^{2} \mathrm{~s}^{-1}$ at $-10^{\circ} \mathrm{C}$. We use this value, coupled with micrometeorological data from Mullins Valley (atmospheric temperature, relative humidity, and soil temperature) to model the sublimation rate of buried glacier ice near the terminus of Mullins Glacier, where the overlying till thickness approaches $70 \mathrm{~cm}$. We find that the ice-lowering rate during the modeled year (2011-2012) was $0.066 \mathrm{~mm}$ under $70 \mathrm{~cm}$ of till, a value which is in line with previous estimates for exceedingly slow rates of ice sublimation. These results provide further evidence supporting the probable antiquity of Mullins Glacier ice and overall landscape stability in upland regions of the MDV.
\end{abstract}

Keywords: Sublimation, buried ice, McMurdo Dry Valleys, Antarctica, diffusion 


\section{Introduction}

The McMurdo Dry Valleys (MDV) of Antarctica have remained predominately ice-free and under hyper-arid polar desert climate conditions since the middle Miocene (Denton et al., 1993; Marchant et al., 1993; Marchant et al., 1996; Marchant et al., 2002; Sugden et al., 1999;

34 Valletta et al., 2015). The preservation of in situ volcanic ash deposits $>10.0 \mathrm{Ma}$ in the

35 Quartermain Mountains (Marchant et al., 1993; Sugden et al., 1995a), as well as the

36 concentration of meteoric beryllium-10 in ancient sediments (Valletta et al., 2015), demonstrate

37 that saturated active-layer cryoturbation - typical of most periglacial regions in the world - has

38 been essentially absent from much of the western MDV over this interval. These findings

39 corroborate the slow rates of landscape change and long-term stability of the region that is

40 afforded by cosmogenic nuclide analyses of surface rocks (Schäfer et al., 2000; Schäfer et al.,

41 1999; Margerison et al., 2005) and glacial-geologic mapping (Lewis and Ashworth, 2015).

42 Moreover, the presence of in-situ ashfall in supraglacial debris suggests that, in places, buried

43 glacier ice has survived for $~ 8.1 \mathrm{Ma}$ (Sugden et al., 1995a). If such ancient ice could be analyzed

44 reliably for gas content it would greatly extend our climate record beyond that possible through

45 the analysis of existing ice cores (e.g., EPICA Dome C, Vostok, GISP). This possibility, along

46 with recent field data suggesting that numerous buried glaciers survive in the coldest and driest

47 parts of the Dry Valleys / Transantarctic Mountains (Mackay and Marchant, 2016) has prompted

48 renewed interest in defining the precise conditions that foster long-term ice preservation in

49 hyper-arid deserts (Kowalewski et al., 2006; Yau et al., 2015; Mackay et al., 2014). The results

50 have been mixed, with modeled estimates for sublimation rates of the same buried ice masses

51 spanning two orders of magnitude, from $10^{-3} \mathrm{~m} \mathrm{yr}^{-1}$ (Hindmarsh et al., 1998) to $10^{-5}{\mathrm{~m} \mathrm{yr}^{-1}}^{-1}$

52 (Kowalewski et al., 2012; Liu et al., 2015) (see also Hagedorn et al., 2007; Hindmarsh et al.,

53 1998; Kowalewski et al., 2012; Kowalewski et al., 2006; Kowalewski et al., 2011; Schorghofer, 
54 2005). If the former rates are correct, then it is unlikely that buried glaciers could survive for $>\sim 1$

$55 \mathrm{Ma}$; if the latter are correct, however, then pockets of buried ice could be preserved for several

56 million years. As yet, there have been no attempts to address this problem through experimental

57 analyses.

In this study, we examine the sublimation rate of Mullins Glacier, a debris-covered alpine

59 glacier located in the inland portion of the MDV, using an experimental approach that measures

60 ice loss via sublimation in an environmental chamber. In its central region, Mullins Glacier is >

61 1.6 Ma (Yau et al., 2015; Mackay and Marchant, 2016); near its terminus, it may be > $3 \mathrm{Ma}$

62 (Mackay and Marchant, 2016).

63

$64 \quad$ 2. Setting

Mullins Glacier is covered with a thin supraglacial till (Mullins till) that is derived from

66 rockfall at the valley head; the till and underlying glacier ice move slowly down valley,

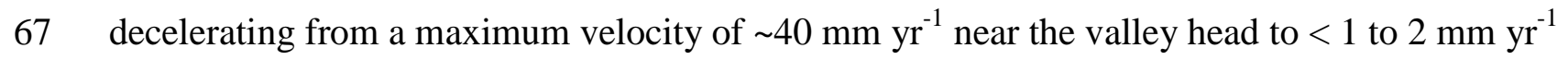

68 on the floor of upper Beacon Valley (Fig. 1) (essentially stagnant, e.g., within measurement error

69 of signals from interferometric synthetic aperture radar; Rignot et al., (2002)). Mullins till is

70 composed primarily of Ferrar Dolerite (>93\%) and undifferentiated sandstone fragments

71 (Kowalewski et al., 2011). The mean annual and summertime atmospheric temperatures at the

72 study site on the glacier are $-23^{\circ} \mathrm{C}$ and $-11^{\circ} \mathrm{C}$ respectively (Kowalewski et al., 2011; Mackay et

73 al., 2014), and snowfall is $<50 \mathrm{~mm} \mathrm{yr}^{-1}$ water equivalent (Fountain et al., 2010). Strong katabatic

74 winds flow from the East Antarctic Ice Sheet (EAIS) at speeds commonly approaching $50 \mathrm{~km} \mathrm{hr}^{-}$

$75{ }^{1}$ (Nylen et al., 2004; Speirs et al., 2010). 


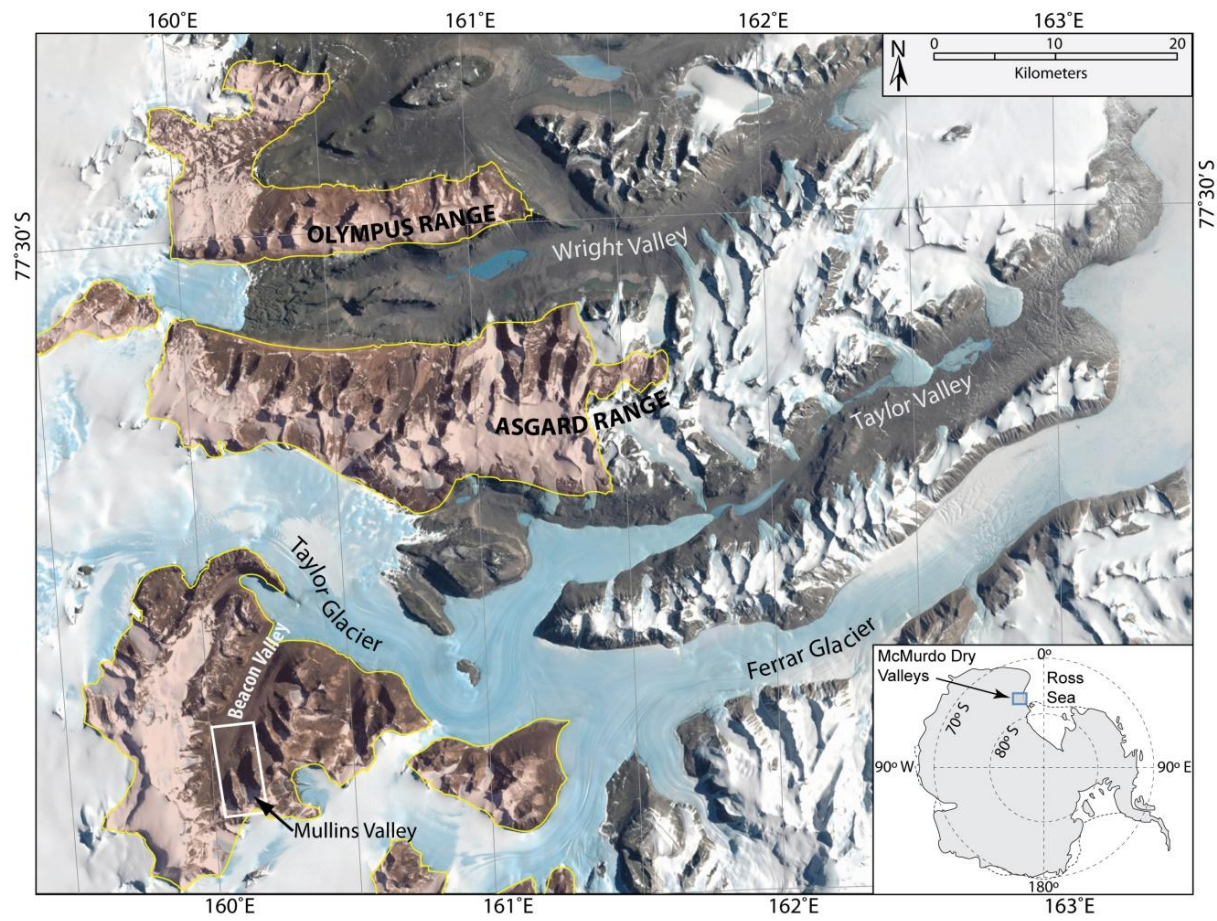

Figure 1. Location of Mullins Glacier. Mullins Glacier occupies the region within the white box, in the lower left portion of the figure; the brown areas outlined in yellow highlight the stable upland zone of the McMurdo Dry Valleys, e.g., the region with negligible saturated active-layer cryoturbation (Marchant and Head, 2007). Inset map shows location of the McMurdo Dry Valleys (MDV); see Figure 2 for details. Figure reproduced from Lamp et al. (2017).

The ice in the upper reaches of Mullins Glacier (within $\sim 4 \mathrm{~km}$ from the valley headwall)

82 is relatively clean, showing only dispersed fines and episodic layers of concentrated debris;

83 beyond $\sim 4 \mathrm{~km}$, the englacial content in Mullins Glacier increases markedly, with visual estimates

84 of shallow ice cores and buried-ice surfaces in soil excavations, along with interpretations of

85 ground penetrating radar, indicating up to 50\% gravel and cobble sized clasts by volume

86 (Mackay et al., 2014). The thickness of Mullins till generally shows a corresponding increase

87 with increasing distance from the headwall (Mackay et al., 2014); at its maximum, Mullins till

88 reaches $\sim 70 \mathrm{~cm}$ in thickness in central and upper Beacon Valley (Kowalewski et al., 2011).

89 Throughout its length, Mullins till is dotted with sublimation polygons, each of which increases

90 in size and maturity with distance down glacier (Marchant et al., 2002). Previous studies have

91 shown that these polygons play an important role in modulating subsurface ice loss (Kowalewski

92 et al., 2012; Marchant et al., 2002): initially, sublimation rates at polygon troughs are high, due 
93 in part to elevated ice loss within unprotected thermal contraction cracks at these sites; as troughs

94 deepen, however, they are in shadow most of the day and experience relatively cool

95 temperatures. Further, deep troughs become preferred sites for snow entrapment, elevating local

96 relative humidity (RH) (Marchant et al., 2002; Kowalewski et al., 2012). The relatively high RH

97 values and cooler atmospheric temperatures tend to retard underlying ice sublimation

98 (Kowalewski et al., 2006; Schorghofer, 2005). The result is that long-term sublimation rates for

99 buried glacier ice with overlying sublimation polygons is limited by the rate of ice loss at

100 polygon centers (Kowalewski et al., 2012).

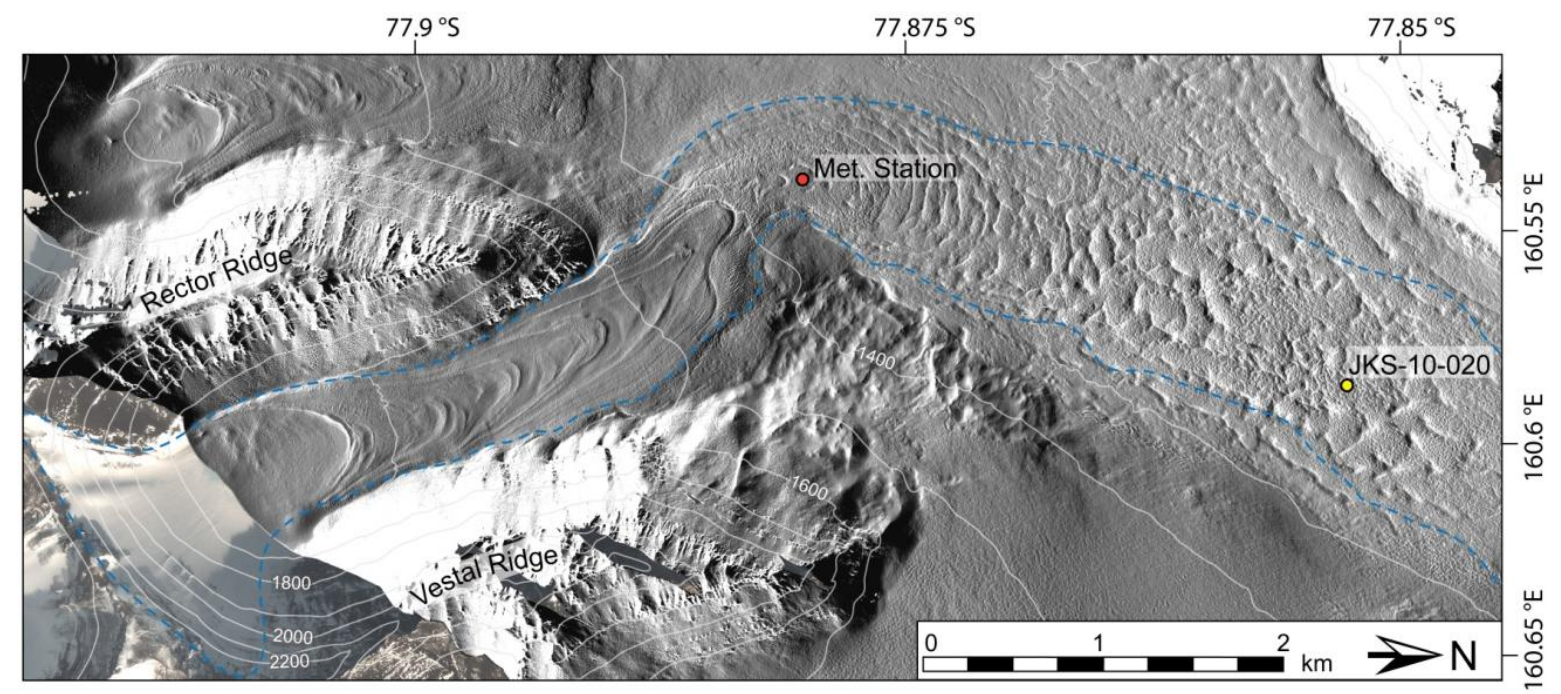

Figure 2. Mullins Glacier, viewed as a hill-shaded relief map from airborne LiDAR (2-m resolution (Schenk et al., 2004)) draped on top of multispectral satellite imagery (GeoEye01, 1.5-m resolution, January 2004) in headwall region (lower left corner) (adapted from Mackay et al., 2014). Flow is from left (Mullins Valley) to right (Beacon Valley). Samples at location JKS-10-020 were collected from the middle of a polygon $\sim 1 \mathrm{~km}$ from the diffuse terminus of Mullins Glacier, central Beacon Valley. Data collected at the long-duration micrometeorological station (Met. Station) is used as input for numerical models described in Section 6. The depth of buried glacier ice at the Met 108 station is $\sim 25 \mathrm{~cm}$, whereas at JKS-10-20 it is $\sim 70 \mathrm{~cm}$. 


\section{Theoretical background}

We assume that Fickian diffusion, characterized by impacts between molecules and

112 driven by concentration gradients, is the dominate vapor transport mechanism from buried ice to

113 the atmosphere at polygon centers in Mullins till (Schorghofer and Aharonson, 2005). Fickian

114 processes dominate diffusive vapor transport through porous media when pore sizes are greater

115 than the mean free path of vapor molecules (Ho and Webb, 2006). Previous studies of sediment

116 in the MDV have shown that Knudsen diffusion, which takes into account molecular interactions

117 with pore walls, can be neglected (Hagedorn et al., 2007; McKay et al., 1998). Thus, for Mullins

118 till, Knudsen diffusion is insignificant. Additionally, we do not include the effects of thermally-

119 driven vapor diffusion or advection, which previous researchers have shown to be less important

120 than Fickian diffusion on annual (and longer) timescales (Schorghofer, 2005).

121 Fick's first law of diffusion is given as:

$$
J=-D_{f} \frac{\partial \rho_{v a p}}{\partial z}
$$

123 where $J$ is the diffusive flux $\left(\mathrm{mol} \mathrm{m}^{-2} \mathrm{~s}^{-1}\right), D_{f}$ is the Fickian diffusion coefficient $\left(\mathrm{m}^{2} \mathrm{~s}^{-1}\right), \rho_{\text {vap }}$ is

124 water vapor density $\left(\mathrm{mol} \mathrm{m}^{-3}\right)$ and $z$ is length $(\mathrm{m})$. For diffusion through porous media, this is 125 rewritten as:

$$
J=-D_{e f f} \frac{\partial \rho_{v a p}}{\partial z}
$$

127 where $D_{\text {eff }}$ is the effective diffusion coefficient $\left(\mathrm{m}^{2} \mathrm{~s}^{-1}\right)$, and,

$$
D_{e f f}=\frac{\phi D_{f}}{\tau}
$$

129 where $\phi$ is the porosity of the sediment, and $\tau$ is the tortuosity. Assuming a linear decrease in $\rho_{\text {vap }}$ 130 throughout the sediment column, and saturated vapor density at the ice-sediment interface, Eq. 2 131 can be rewritten as: 


$$
J=-D_{e f f} \frac{\rho_{s a t}-\rho_{a t m}}{L}
$$

133 where $L$ is the sediment thickness, $\rho_{\text {sat }}$ is the saturated vapor density at the temperature of the ice134 sediment interface, and $\rho_{\text {atm }}$ is the vapor density in the atmosphere.

135 We can relate vapor density $\left(\rho_{\text {sat }}, \rho_{\text {atm }}\right)$ to vapor pressure $\left(P_{\text {sat }}, P_{\text {atm }}\right)$ using the ideal gas 136 law:

$$
\rho_{v a p}=\frac{P_{v a p} M_{w}}{R T}
$$

138 where $P_{\text {vap }}$ is vapor pressure, $M_{w}$ is the molecular mass of water $\left(18.02 \mathrm{~g} \mathrm{~mol}^{-1}\right), R$ is the gas

139 constant $\left(8.314 \mathrm{~J} \mathrm{~mol}^{-1} \mathrm{~K}^{-1}\right)$, and $T$ is temperature.

Substituting Eq. 5 into Eq. 4 we find:

$$
J=-\frac{D_{e f f} M_{w}}{L R}\left[\frac{P_{s a t}}{T_{\text {ice }}}-\frac{P_{a t m}}{T_{a t m}}\right]
$$

142 where $P_{\text {sat }}$ is the saturation vapor pressure at the temperature of the ice-sediment interface $\left(T_{\text {ice }}\right)$,

$143 P_{a t m}$ is the vapor pressure in the atmosphere and $T_{a t m}$ is the atmospheric temperature. The value

144 of $P_{\text {sat }}$ over ice can be approximated by the polynomial equation given in Lowe (1977) and

145 Hagedorn et al. (2007):

$$
P_{\text {sat }}=(A+T(B+T(C+T(D+T(E+T(F+G T)) / H
$$

147 where $P_{\text {sat }}(\mathrm{Pa})$ is the saturated vapor pressure at $T\left({ }^{\circ} \mathrm{C}\right)$ over ice. The coefficient values are: $\mathrm{A}=$ 6.109177956, $\mathrm{B}=0.503469897, \mathrm{C}=1.886013408 \times 10^{-2}, \mathrm{D}=4.176223716 \times 10^{-4}, \mathrm{E}=$ $5.824720280 \times 10^{-6}, \mathrm{~F}=4.838803174 \times 10^{-8}, \mathrm{G}=1.838826904 \times 10^{-10}$, and $\mathrm{H}=0.009998$.

151 sublimation rate, $E$, in units of length per time. Rearranging, this gives:

$$
E=-\frac{D_{\text {eff }} M_{w} P_{\text {sat }}}{L R T_{\text {ice }} \rho_{\text {ice }}}\left[1-\frac{T_{\text {ice }} P_{\text {atm }}}{T_{\text {atm }} P_{\text {sat }}}\right]
$$


Eq. 8 is used in conjunction with our experimental measurements of sublimation loss (see

154 below) to estimate the effective diffusion coefficient in Mullins till and to predict the annual loss 155 of ice from Mullins Glacier using field measured values of temperature, RH, and air pressure.

\section{4. Experimental methods}

$158 \quad 4.1$ Physical properties of Mullins till

159 4.1.1 Generation of the Mullins Composite (MC) standard

160 MC consists of a conglomeration of Mullins till sourced from separate sample sites on

161 Mullins Glacier; the composite was sorted by grain size, and then recombined to match a

162 representative sediment sample with a prescribed grain size distribution. The representative

163 sample for MC is JKS-10-020, which comes from near the glacier terminus (Figure 2) at 1250

164 m.a.s.l. and best represents the till texture at the location on Mullins Glacier where some of the

165 oldest ice is preserved (Kowalewski et al., 2011). JKS-10-020 was taken from within $10 \mathrm{~cm}$ of

166 the till surface. Although till texture varies with depth to the buried-ice interface, distance from

167 the headwall, and location with respect to polygonal surfaces, we believe this sample provides an

168 adequate representation of Mullins till for the purposes of this initial study.

169 To prepare the MC, the grain size distribution of our representative sample, JKS-10-020,

170 was first determined by sieving samples in the field (to separate the $<16 \mathrm{~mm}$ fraction from the $>$

$17116 \mathrm{~mm}$ fraction) and then sieving the sample (dry) at Boston University through a stack of 9

172 sieves: 8 mm, 4 mm, 2 mm, 1 mm, $500 \mu \mathrm{m}, 250 \mu \mathrm{m}, 125 \mu \mathrm{m}, 63 \mu \mathrm{m}$, and pan $(<63 \mu \mathrm{m})$. From

173 this analysis, we determined that JKS-10-020 is a coarse-grained, well-graded sand-and-gravel

174 mixture containing $<2 \%$ silt and clay sized particles (Figure 3, see also table provided in

175 supplementary material). This grain size distribution was replicated in MC by combining 
176 additional Mullins till samples, sieving as described above, and then combining the fractions to

177 match the weight percentages in JKS-10-020. A new MC sample was prepared prior to each

178 sublimation experiment in order to ensure that the grain size distribution for each experiment was

179 constant and unaffected by gravitational settling during storage. The Mullins till samples were

180 stored in Whirl-Pak ${ }^{\circledR}$ bags and sealed plastic containers from the time of their initial removal

181 from the field site until their use in this study which minimized the duration of exposure to the 182 atmosphere and the amount of water adsorption/desorption.

Only particle sizes $<8 \mathrm{~mm}$ were used in the experiments; this maximum grain-size value

184 was chosen due to the relatively narrow inner diameter (3.25 inches or $82.55 \mathrm{~mm})$ of the sample

185 containers used in our sublimation experiments (Figure 4). Kowalewski et al. (2011) directly

186 measured the in situ porosity of Mullins till, reporting values ranging from 0.29-0.31. To

187 determine porosity in this study, we measured the bulk density $\left(\rho_{B}\right)$ of the MC sediment $(\sim 1896$

$\left.188 \mathrm{~kg} \mathrm{~m}^{-3}\right)$; assuming a grain density $\left(\rho_{G}\right)$ of $\sim 2700 \mathrm{~kg} \mathrm{~m}^{-3}$, the porosity $(\phi)$ of MC is $\sim 29.8 \%(\phi=1-$

$\left.189 \rho_{B} / \rho_{G}\right)$, which is in accord with porosity at polygon centers reported Kowalewski et al. (2011),

190 e.g., 29.5\%.

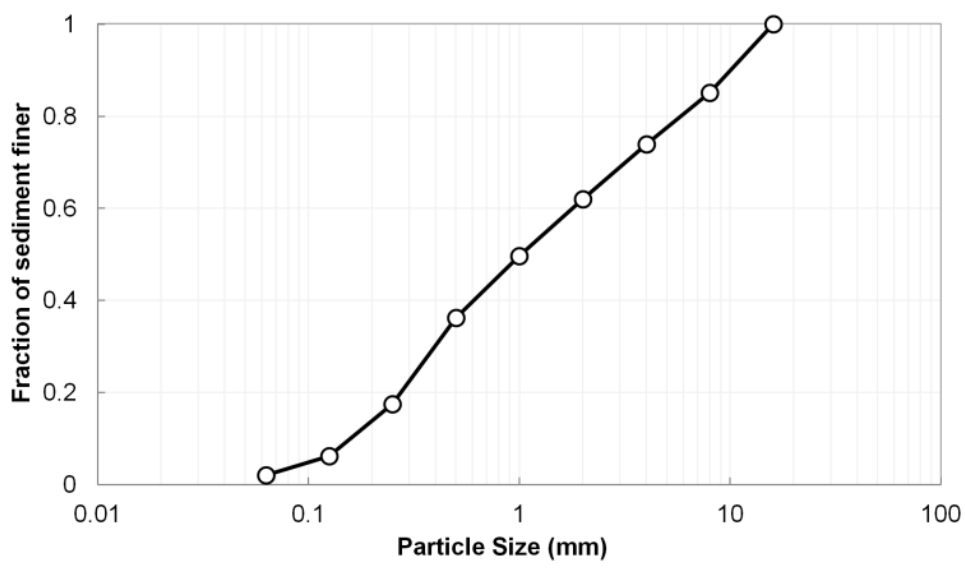

192 Figure 3. Cumulative particle size distribution of JKS-10-20 and the Mullins Composite (MC).

193 4.1.2 Salts in Mullins till/MC 
A $50 \mathrm{~g}$ sample of MC sediment was rinsed with deionized water $(100 \mathrm{~mL})$, and the

195 supernatant allowed to evaporate, leading to the precipitation of salt crystals. These crystals were

196 analyzed in Boston University's X-ray Diffraction Lab on a Rigaku MiniFlex Powder

197 Diffractometer. The diffraction patterns, analyzed using the Jade 9 data analysis program,

198 showed evidence of nitratine $\left(\mathrm{NaNO}_{3}\right)$, gypsum $\left(\mathrm{CaSO}_{4} \cdot 2 \mathrm{H}_{2} \mathrm{O}\right)$, and halite $(\mathrm{NaCl})$ (see Figure $\mathrm{S} 1$

199 in the supplementary material). Because of the manner in which we admixed samples to create

200 MC, the distribution of these salts in MC is most likely uniform with depth; however, discrete

201 salt layers are common in sublimation till in the western MDV (Bao and Marchant, 2006; Bao et

202 al., 2008). The inclusion of salt horizons in our experiments would likely result in lower

203 sublimation rates as these low-porosity layers hinder vapor transport in the till column

204 (Kowalewski et al., 2012).

205

\subsection{Environmental chamber setup}

We used an ESPEC environmental chamber, model EPX-3H, coupled with an oil-free

208 Atlas Copco air compressor and dry-air purge system (capable of producing air with a dew point

$\left.209<-30^{\circ} \mathrm{C}\right)$ to analyze sublimation and vapor transport through the MC standard. The internal

210 chamber compartment (Figure 4B) is equipped with two analytical balances set on anti-vibration

211 pads, a suite of Onset Computer Corporation HOBO micrometeorological sensors (air

212 temperature, relative humidity $(\mathrm{RH})$ and air pressure; see specifications in supplementary

213 material), and a Plexiglas air shield to block air flow from the chamber's air inlet from passing

214 directly over the sample. The ice core/sediment containers are $\sim 30 \mathrm{~cm}$ tall and made from rigid,

215 clear butyrate tubing with a 3.25 in $(82.55 \mathrm{~mm})$ inner diameter and capped at one end (Figure

216 4C). Readings from an anemometer mounted in the chamber during experiments showed that the 
217 air speed at the height of the samples was generally between $0-0.1 \mathrm{~m} / \mathrm{s}$. The chamber temperature

218 was set to $-10^{\circ} \mathrm{C}$, varying $\leq 0.1^{\circ} \mathrm{C}$ during the course of each experiment. At $-10^{\circ} \mathrm{C}$, $\mathrm{RH}$ values

219 varied between $12 \%-22 \%$ over the course of all experiments, reflecting fluctuations in the

220 ambient air conditions at the compressor intake; however, the RH during each individual

221 experiment remained relatively stable (see Supplemental Information).

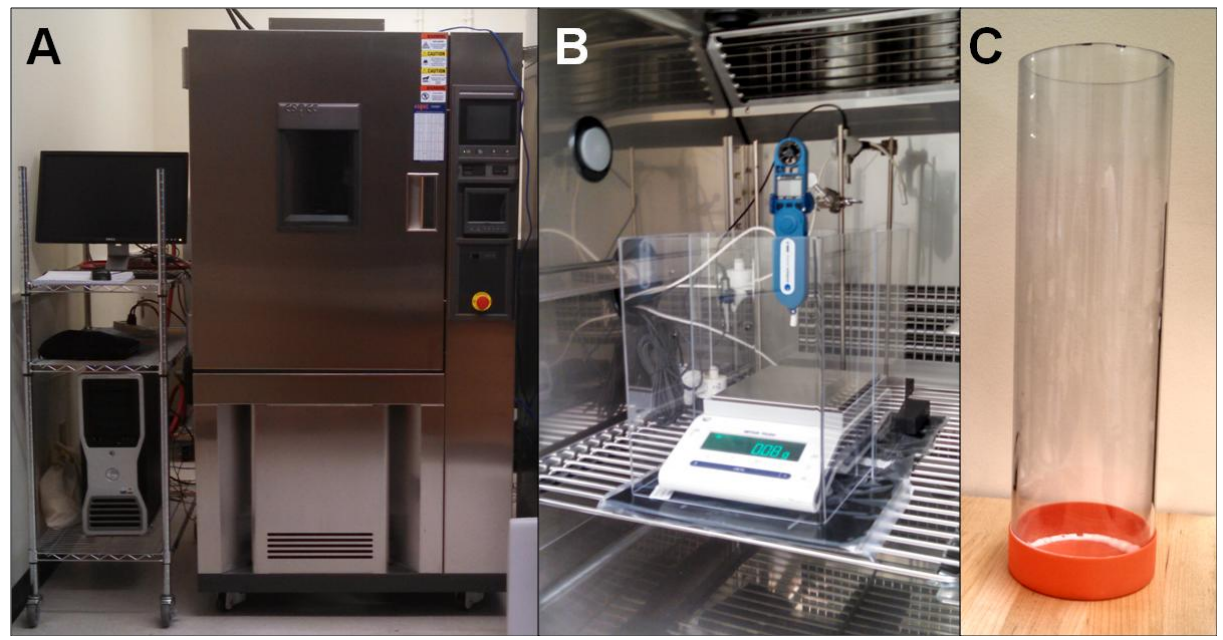

Figure 4. Experimental setup of sublimation experiments. (A) The ESPEC environmental Chamber, model EPX-3H.

(B) The inside of the test chamber. The micrometeorological sensors and balance connections are fed through a port on the left-hand side of the chamber which is insulated with foam. A balance is seated on an anti-vibration pad, and is surrounded with a Plexiglas air shield; a second air shield, which provides additional protection, is not pictured. A battery powered anemometer hangs above the balance. (C) A typical butyrate sample container $(\sim 30 \mathrm{~cm}$ tall) that would hold a core of ice and overlying Mullins Composite of varying thickness.

\subsection{Balances}

Two Mettler Toledo MS4002S laboratory balances (4200 g capacity and a readability of

$2310.01 \mathrm{~g}$ ) were used within the environmental chamber to record changes in the mass of studied ice

232 samples. Prior to conducting individual experiments, we tested the stability of the balances at

233 subzero temperatures. The balances were placed into the chamber at $-10{ }^{\circ} \mathrm{C}$ for 24 hours, loaded

234 with standard weights of $500 \mathrm{~g}$ to $1500 \mathrm{~g}$, and masses were recorded every 60 seconds. The

235 results of this test showed the balances maintained high precision but required a start-up period

236 of $\sim 2-3$ hours to enable the scales to equilibrate to the chamber temperatures (Figure $\mathrm{S} 2$ in the 
237 supplementary material). Therefore, we exclude the first 3 hours of data in all sublimation

238 experiments in order to account for scale equilibration.

$240 \quad 4.4$ Experimental procedures

241 For each experiment, butyrate sample containers $(\sim 30 \mathrm{~cm}$ tall; Figure $4 \mathrm{C})$ were filled

242 with deionized water to a pre-determined height and frozen at $-10^{\circ} \mathrm{C}$ to produce a $\sim 20-30 \mathrm{~cm}$ ice

243 core; if necessary the ice surface was shaved down and a thin layer of water frozen on top to

244 create a flat interface between ice and sediment. MC was then added to the ice surface until the

245 sediment was flush with the rim of the container. To prevent melting at the ice-sediment

246 boundary, the MC was pre-cooled to $-10^{\circ} \mathrm{C}$ before being added to the ice core. Measurements of

247 mass loss were recorded every 60 seconds, and experiments were run for varying lengths of time,

248 ranging from $\sim 24$ hours for bare ice to $\sim 2$ weeks for the thickest sediment cover. All experiments

249 were run at $-10^{\circ} \mathrm{C}$ in order to (1) be sufficiently far from the melting point of ice, and (2)

250 preserve the life of the analytical balances. Additionally, a MC sample was run by itself in the

251 chamber at $-10^{\circ} \mathrm{C}$ to determine whether desorption from the sediment was in part responsible for

252 any mass loss seen in the sublimation experiments.

253 At the conclusion of each experiment, the sublimation rate was determined by fitting a

254 linear trend line to the measured mass versus time data. The RH and air pressure for each

255 experiment were determined by averaging the measured $\mathrm{RH}$ and air pressure over the portion of

256 the experiment used in the sublimation rate calculation.

257

258 6. Results

$259 \quad 6.1$ Experimental results 
261 thicknesses of overlying MC samples (Table 1). Mass loss versus time plots for each run are

262 provided in the supplementary material; the data show that our 60 second data-recording interval

263 is sufficient to produce a strong trend, despite chamber vibrations adding noise to the balance

264 readings. We found no evidence for mass loss due to desorption from the isolated MC sediment

265 (no ice) experiment.

266

\section{$267 \quad 6.2$ Diffusivity of Mullins till}

268 We use the experimental results and Eq. 8 to determine the effective diffusivity in

269 Mullins till. Assuming steady-state conditions and a constant temperature profile in the sediment 270 during our experiments (i.e., $T_{\text {ice }}=T_{\text {atm }}=T$ ), Eq. 8 reduces to:

$$
E=-\frac{D_{\text {eff }} M_{w} P_{\text {sat }}}{L R T \rho_{\text {ice }}}[1-R H]
$$

272 where $R H$ is the relative humidity, equal to $P_{a t m} / P_{\text {sat }}$, and $\rho_{\text {ice }}$ is the density of ice at $-10^{\circ} \mathrm{C}$ which

273 is $\sim 918.2 \mathrm{~kg} \mathrm{~m}^{-3}$ (Haynes, 2015). In order to accurately determine the $\mathrm{RH}$ at $-10^{\circ} \mathrm{C}$, the $\mathrm{RH}$

274 values from the Onset HOBO sensors used in the chamber (which are reported with respect to

275 liquid water) were multiplied by the ratio of the saturated vapor pressure over water to the

276 saturated vapor pressure over ice using the polynomial equations in Lowe (1977).

277 We correct for fluctuations in RH and air pressure $\left(P_{\text {air }}\right)$ during our experiments using:

$$
E_{\text {corr }}=E_{\text {exp }}\left[\left(\frac{1-R H_{\text {corr }}}{1-R H_{\text {exp }}}\right)\left(\frac{P_{\text {air }, \text { exp }}}{P_{\text {air }, \text { corr }}}\right)\right]
$$

279 where $E_{\text {corr }}$ is the corrected sublimation rate and $E_{\text {exp }}$ is the experimentally determined

280 sublimation rate. Using Eq. 10, each experimentally derived sublimation estimate made at

281 conditions of $R H_{\text {exp }}, P_{\text {air exp }}$ can be converted to the expected sublimation rate at consistent $R H$,

$282 P_{\text {air }}$ values. In order to accurately compare the sublimation results between experimental runs, we 
283 corrected the sublimation rate for each experiment using Eq. 10 to represent the following

284 ambient conditions: $T=-10^{\circ} \mathrm{C}, R H_{\text {corr }}=40 \%, P_{\text {air }, \text { corr }}=850 \mathrm{mbar}$ (Table 1$)$.

285 We use values of $E_{c o r r}$ at each sediment thickness to approximate the value of $D_{\text {eff }}$ for

286 Mullins till according to Eq. 9. We first define a parameter $\beta$ :

$$
\beta=\frac{M_{w} P_{\text {sat }}}{L R T \rho_{\text {ice }}}[1-R H]
$$

288 So that

$$
E_{\text {corr }}=\beta D_{\text {eff }}
$$

290 From the slope of a $E_{c o r r}$ versus $\beta$ plotted for each sediment thickness (Figure 5) we can now

291 estimate the value of $D_{\text {eff }}$ for Mullins till. For a chamber temperature of $-10^{\circ} \mathrm{C}, 40 \% \mathrm{RH}$, and an

292 atmospheric pressure of 850 mbar, our experimental results indicate an effective diffusivity of

$293(5.2 \pm 0.5) \times 10^{-6} \mathrm{~m}^{2} \mathrm{~s}^{-1}$ for Mullins till. Next, we estimate the tortuosity - the ratio of the average

294 "tortuous" path length traveled by a molecule through interconnected pores to the apparent

295 straight-line path length (Hillel, 1998) - in the sediment using Eq. 3 with our known value of

296 porosity $\left(0.298\right.$, from Section 4.1.1) and an estimate of $D_{f}\left(\right.$ in $\left.\mathrm{m}^{2} \mathrm{~s}^{-1}\right)$ for water vapor in air given

297 as (Schwertz and Brow, 1951):

$$
D_{f}=\left(1.87 \times 10^{-10}\right) T^{2.072} \frac{P_{0}}{P}
$$

299 where $P_{0}=1013$ mbar, and $T$ and $P$ are the values used in our experimental determination of $D_{\text {eff }}$

$300 \quad\left(-10^{\circ} \mathrm{C}\right.$ and 850 mbar $)$. With our estimated $D_{\text {eff }}$ value, we arrive at an estimated tortuosity in the

\begin{tabular}{|c|c|c|c|c|c|}
\hline $\begin{array}{l}\text { Sediment } \\
\text { depth } \\
(\mathrm{mm})\end{array}$ & $\begin{array}{c}\text { Average } \\
\text { RH (\%) }\end{array}$ & $\begin{array}{c}\text { Average } \\
\text { pressure } \\
\text { (mbar) }\end{array}$ & $\begin{array}{c}\text { Experimental } \\
\text { sublimation rate } \\
\left(10^{-10} \mathrm{~m} \mathrm{~s}^{-1}\right)\end{array}$ & $\begin{array}{c}\text { Corrected } \\
\text { sublimation rate } \\
\left(10^{-10} \mathrm{~m} \mathrm{~s}^{-1}\right)\end{array}$ & $\begin{array}{c}\beta \\
\left(10^{-5} \mathrm{~m}^{-1}\right)\end{array}$ \\
\hline 0 & 21.59 & 1026 & 208 & 192 & -- \\
\hline 0 & 21.59 & 1026 & 163 & 150 & -- \\
\hline 6 & 20.20 & 1009 & 11.8 & 10.6 & 23.3 \\
\hline 7 & 12.24 & 1018 & 12.4 & 10.2 & 19.9 \\
\hline
\end{tabular}

$301 \quad$ MC sediment of $\sim 1.33$.

302 Table 1. Results from sublimation experiments. 


\begin{tabular}{cccccc}
\hline 11.5 & 12.24 & 1018 & 9.46 & 7.75 & 12.1 \\
12.5 & 20.20 & 1009 & 7.55 & 6.74 & 11.1 \\
18 & 17.31 & 1028 & 5.45 & 4.78 & 7.76 \\
30.5 & 17.31 & 1028 & 3.50 & 3.07 & 4.58 \\
42 & 17.39 & 1017 & 1.91 & 1.66 & 3.32 \\
69 & 17.39 & 1017 & 1.10 & 0.958 & 2.02 \\
\hline
\end{tabular}

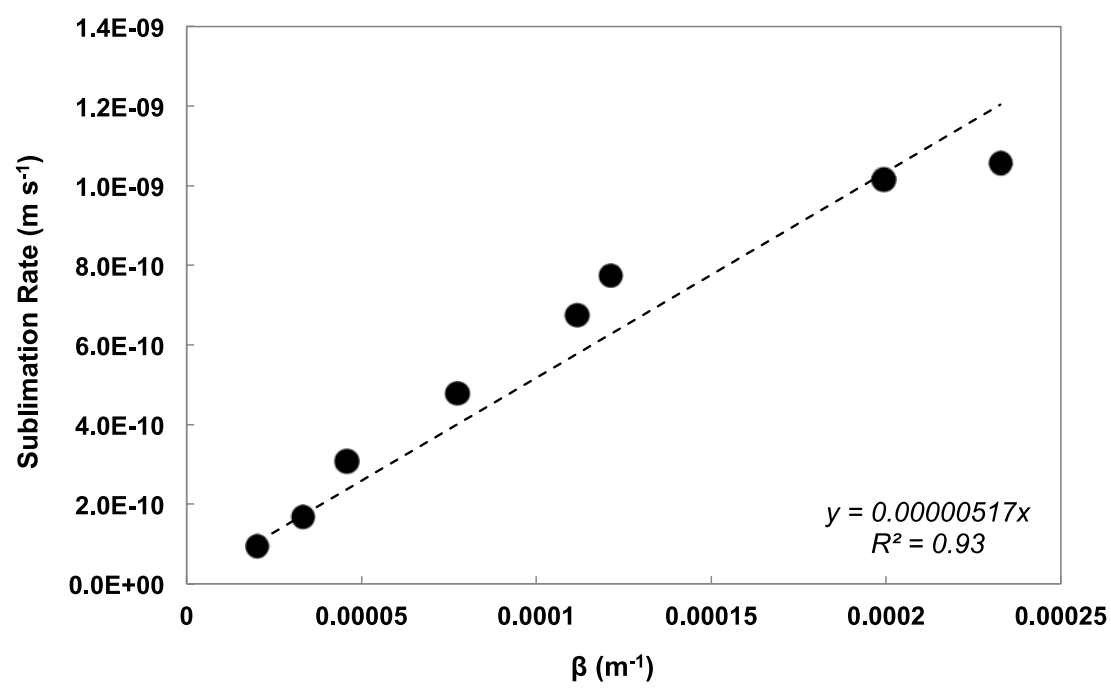

306 Figure 5. Sublimation rate versus $\beta$. The value of $D_{\text {eff }}$ is approximated by the slope of the line to be $(5.2 \pm 0.5) \times 10^{-6}$ $307 \mathrm{~m}^{2} \mathrm{~s}^{-1}$. The $\mathrm{R}^{2}$ value for the line is 0.93 .

\subsection{Sublimation rates on Mullins Glacier}

We now utilize our estimate of $D_{e f f}$, in conjunction with measured micrometeorological

310 values in Beacon Valley, to estimate the sublimation rate near the terminus of Mullins Glacier in

311 Beacon Valley, where the till thickness approaches $70 \mathrm{~cm}$ (Kowalewski et al., 2011). Using an

312 existing multi-year record of air temperature, $\mathrm{RH}$, and pressure, as well as subsurface soil

313 temperatures at depths of 1 to $25 \mathrm{~cm}$ in Mullins till, we first estimate the thermal diffusivity of

314 Mullins till and then use this value to calculate the expected till temperature at depths of 40, 50,

31560 , and $70 \mathrm{~cm}$. We then estimate the average value of $D_{\text {eff }}$, which itself changes with temperature

316 and air pressure, in the sediment column at each time interval. Lastly, we use Eq. 9 to determine

317 the sublimation rate of Mullins Glacier ice at each time step, and then calculate the annual

318 sublimation rate for till thicknesses from 1 to $70 \mathrm{~cm}$. 


\subsubsection{Micrometeorological data}

Multi-year records of air temperature, $\mathrm{RH}$, and pressure at $2 \mathrm{~cm}$ above the till surface, as

322 well as subsurface soil temperatures in Mullins till at depths of 1, 10, 20, and $25 \mathrm{~cm}$ depth (the

323 local depth to buried glacier ice at the monitoring location) are available from a

324 micrometeorological station located halfway between the glacier headwall and terminus (Figure

325 2). The data were recorded every 30 minutes using Onset HOBO dataloggers and smart sensors.

326 In this study, we use a year of continuous data from January 1, 2011-January 1, 2012. We select

327 this dataset because we have a continuous, unbroken record for the entire year, and the average

328 values are similar to the multi-year averages in this location (Table 2).

The time series and average micrometeorological data for the year of interest are

330 provided in Figures 6, 7, and Table 2. The RH values for air temperatures $<0^{\circ} \mathrm{C}$ were corrected

331 for RH over ice as described in section 6.2.
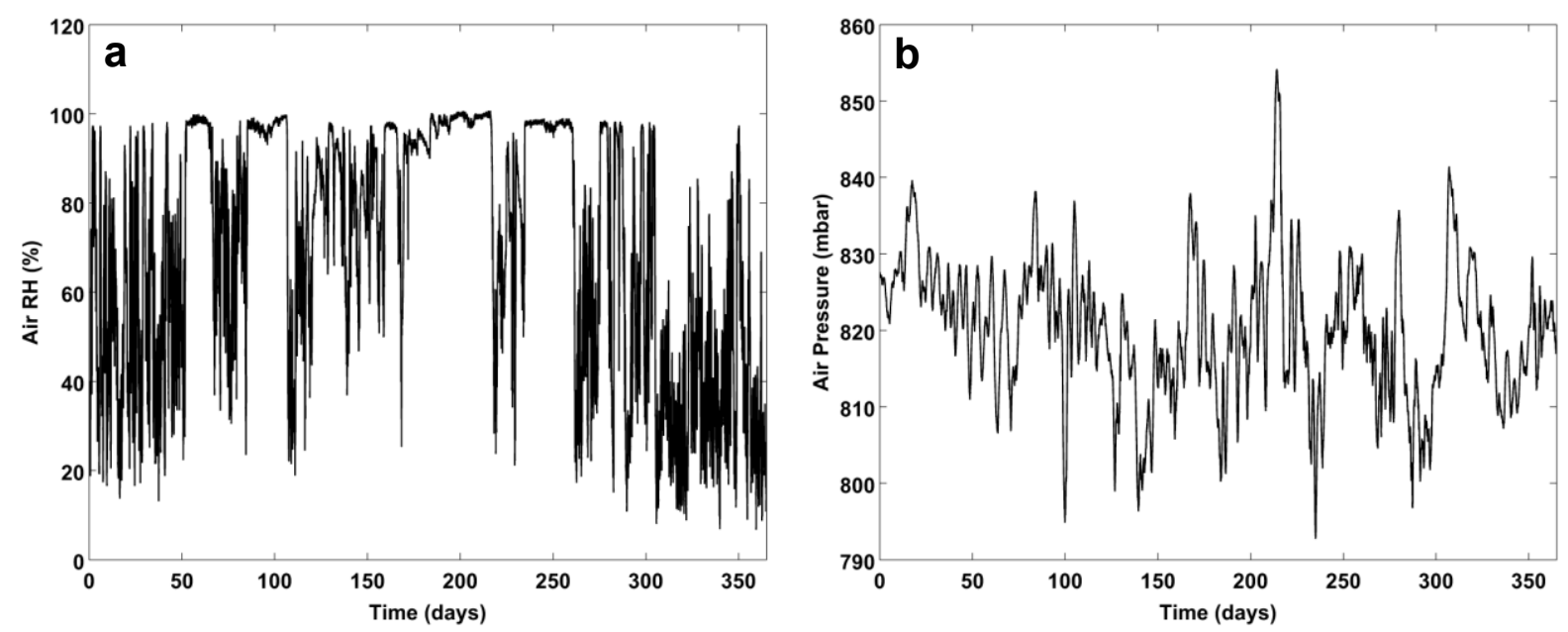

Figure 6. 2011 air pressure and adjusted RH from Mullins Glacier. Time 0 corresponds to January 1, 2011. (a): RH of 


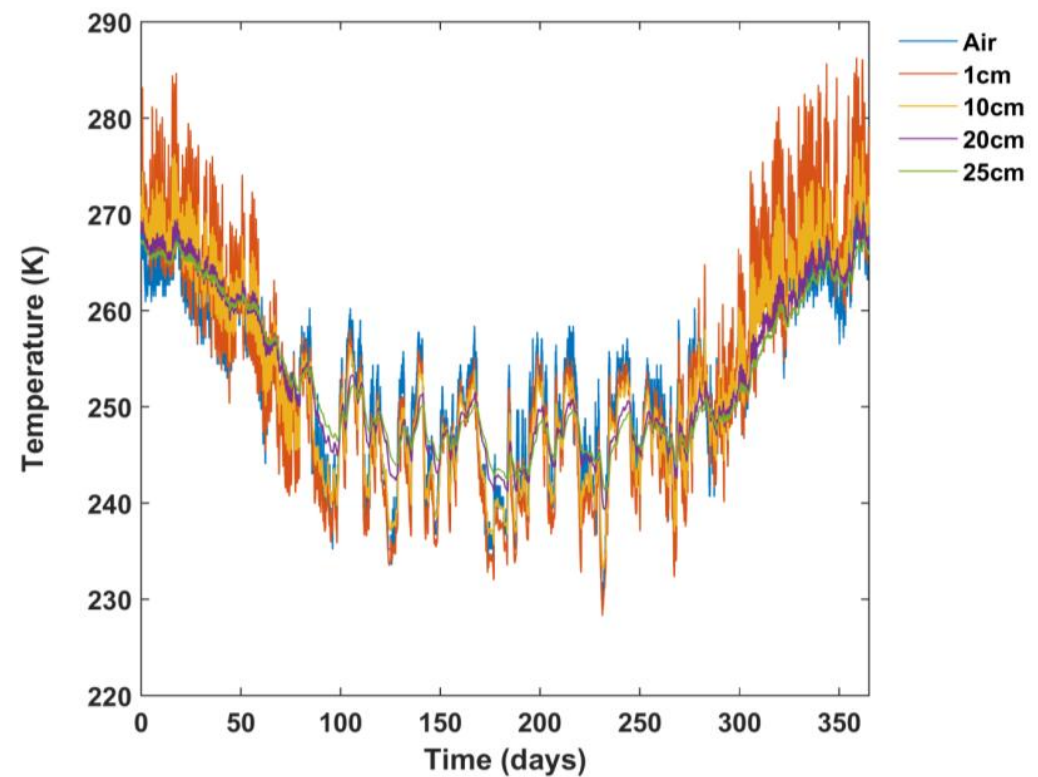

Figure 7. 2011 air and till temperatures measured on Mullins Glacier. Data series starts at January 1, 2011 and ends on December 31, 2012.

Table 2. Summary of meteorological measurements on Mullins Glacier.

\begin{tabular}{|c|c|c|c|c|c|c|c|c|c|c|c|}
\hline & \multicolumn{9}{|c|}{ Temperatures $\left({ }^{\circ} \mathrm{C}\right)$} & \multirow{2}{*}{$\mathrm{RH}^{1}(\%)$} & \multirow{2}{*}{$\begin{array}{c}\text { Pressure } \\
\text { (mbar) }\end{array}$} \\
\hline & Air & $1 \mathrm{~cm}$ & $10 \mathrm{~cm}$ & $20 \mathrm{~cm}$ & $25 \mathrm{~cm}$ & $40 \mathrm{~cm}$ & $50 \mathrm{~cm}$ & $60 \mathrm{~cm}$ & $70 \mathrm{~cm}$ & & \\
\hline 2011 Average & -20.5 & -20.2 & -20.2 & -20.1 & -20.4 & -20.2 & -20.2 & -20.2 & -20.2 & 70.2 & 820 \\
\hline 2011 Maximum & 2.46 & 13.1 & 4.48 & -3.07 & -5.7 & -12.4 & -13.5 & -14.4 & -15.2 & $101^{1}$ & 854 \\
\hline 2011 Minimum & -43.2 & -44.9 & -40.1 & -33.8 & -31.9 & -28.0 & -27.0 & -26.1 & -25.3 & 6.75 & 793 \\
\hline Multi-year average ${ }^{2}$ & -21.5 & -21.2 & -21.2 & -21.0 & -21.3 & -- & -- & -- & -- & -- & -- \\
\hline
\end{tabular}

\subsubsection{Estimate of temperatures at depth}

345 first approximate the temperature wave at depth using the measured till temperatures (see

346 supplementary material). We find a best fit cosine curve for each temperature wave and then

347 approximate the thermal diffusivity $(\kappa)$ in the till using:

$$
\ln A_{z}=\ln A_{0}-\frac{z}{\sqrt{T \psi \kappa / \pi}}
$$

where $\psi$ is the period, $z$ is the depth, $A_{0}$ is the amplitude of the temperature wave at the surface, 
352 estimated thermal diffusivity for Mullins till of $\sim 2.1 \times 10^{-7} \mathrm{~m}^{2} \mathrm{~s}^{-1}$, which is in line with previous

353 estimates for supraglacial till and other sediment in the MDV (Campbell and Claridge, 2006;

354 Kowalewski et al., 2011). We then approximate the temperature wave at $\mathrm{z}=40,50,60$, and 70

355 cm by estimating for each depth the amplitude via Eq. 14, and the phase shift by the best fit slope

356 of the phase shift vs. $z$ from the measured temperatures at shallower depths.

\subsubsection{Sublimation model}

We now use the measured $(1,10,20$, and $25 \mathrm{~cm}$ depth) and estimated (40, 50, 60, and 70

$360 \mathrm{~cm}$ depth) Mullins till temperatures, coupled with the estimate of $D_{\text {eff }}$ from the chamber

361 experiments, to approximate the sublimation of Mullins Glacier ice under various thickness of

362 till.

The diffusion coefficient is not constant, but has been found to correlate approximately

364 with temperature and pressure as (Chen and Othmer, 1962):

$$
D_{f} \propto \frac{T^{\frac{3}{2}}}{P}
$$

366 We estimate $D_{\text {eff }}$ at each depth and time using:

$$
D_{e f f}=D_{e f f, \exp } \frac{P_{\text {exp }}}{P} \frac{T^{\frac{3}{2}}}{T_{\text {exp }}^{\frac{3}{2}}}
$$

368 where $P_{\text {exp }}$ and $T_{\text {exp }}$ are the pressure and temperature at which the experimentally determined

369 value of $D_{\text {eff,exp }}$ was calculated, $P$ and $T$ are the average values of air pressure and temperature

370 between each temperature record location. At each 30-minute time interval, we calculate $D_{\text {eff }}$ for

371 depth segments of the till column: 0-1 cm depth, 1-10 cm depth, 10-20 cm depth, 20-25 cm

372 depth, and 25-base depth, depending on the total thickness of the column modeled. We

373 determine a depth-averaged value of diffusivity $\left(D_{\text {eff,avg }}\right)$ from these values and apply it to the 
374 total sediment column at each time step. The air pressure is assumed to be constant through the

375 till column at each time step.

376 The density of ice $\left(\rho_{\text {ice }}\right)$ also varies slightly with temperature. We approximate this

377 variability over the range of $0^{\circ} \mathrm{C}$ to $-50^{\circ} \mathrm{C}$ using a linear fit to density measurements (Haynes,

378 2015) resulting in:

$$
\rho_{\text {ice }}=-0.13514 T_{\text {ice }}+953.719
$$

380 where $T_{i c e}$ is the temperature in $\mathrm{K}$ at the ice-sediment boundary.

Finally, we solve for the sublimation rate at each 30-minute time step using:

$$
E(t)=-\frac{D_{e f f, a v g}(t) M_{w}}{z R \rho_{\text {ice }}(t)}\left[\frac{P_{\text {sat }, z}(t)}{T_{z}(t)}-\frac{P_{s a t, a i r}(t) R H_{a i r}(t)}{T_{a i r}(t)}\right]
$$

383 where $P_{s a t, z}$, and $T_{z}$ are the conditions at the base of the till column (the ice table depth) assuming 384 saturated conditions at the ice-sediment interface, and $P_{\text {sat,air }}, R H_{\text {air }}$, and $T_{\text {air }}$ are the conditions at 385 the till surface. Figure 8 shows the estimated annual sublimation rate for various till thickness, as 386 well as the sublimation rate at each modeled time step for a maximum till depth of $70 \mathrm{~cm}$. The 387 rate of ice loss under $1 \mathrm{~cm}$ of till is $1.64 \mathrm{~mm} \mathrm{yr}^{-1}$, and under $70 \mathrm{~cm}, 0.066 \mathrm{~mm} \mathrm{yr}^{-1}$; these values 388 represent the net change including sublimation and condensation (i.e., vapor flow towards the ice 389 surface). During the model, the average $D_{\text {eff }}$ throughout the $70 \mathrm{~cm}$-thick sediment column ranged 390 from $4.7 \times 10^{-6}$ to $5.5 \times 10^{-6} \mathrm{~m}^{2} \mathrm{~s}^{-1}$ with an average of $5.1 \times 10^{-6} \mathrm{~m}^{2} \mathrm{~s}^{-1}$. Using the sublimation rate 391 vs. till thickness data (Fig. 8a), we estimate the time to reach a $70 \mathrm{~cm}$ sublimation till cover to be $392 \sim 0.4$ and 4.2 Myr for $10 \%$ and $1 \%$ ice sediment content respectively. 

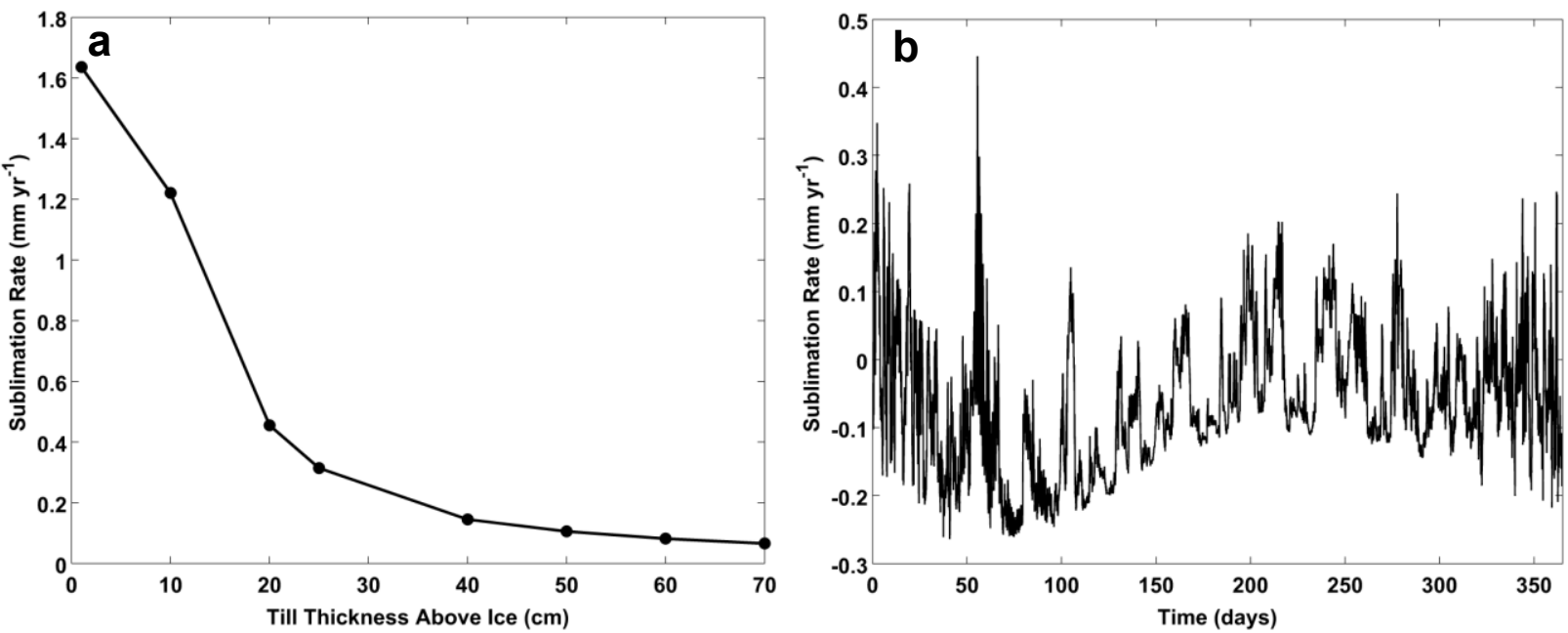

Figure 8. Modeled sublimation rates for Mullins Glacier. (a) Average annual sublimation rates for till thicknesses of 1 $\mathrm{cm}$ to $70 \mathrm{~cm}$. (b) Sublimation rate at each time step for ice under $70 \mathrm{~cm}$ of till. Time series reflects estimates of the sublimation rate at 30-minute time intervals from January 1, 2011 to December 31, 2012. A negative value represents mass loss via sublimation, and a positive value represents vapor diffusion inward towards the buried ice surface. For $24.3 \%$ of the modeled time steps, vapor was transported downward toward the ice surface (i.e., the flux was $>0$ ).

\section{Discussion}

\subsection{Factors influencing diffusivity and sublimation rate} affect its chemical and physical properties. For example, a recent study by Kossacki and LeliwaKopystynski (2014) showed that mineral impurities affect the temperature dependence of ice sublimation rates. In future experiments, polycrystalline ice representing the measured debris and salt content of glacial ice will be used to better understand glacial sublimation rates. in modulating the sublimation rate of buried ice through the Mullins till, snowfall events are at

411 least partially captured in our model by our RH measurements, which approach $100 \%$ during

412 periods of snow (see Figure 6). McKay (2009) showed that snow cover has a stabilizing effect on 
413 sublimation of buried ice bodies, and sublimation models by Liu et al. (2015) and Kowalewski et

414 al. (2012) show that snow cover significantly reduces sublimation rates in this region.

415 Schorghofer (2009) showed that percolating meltwater, perhaps induced via albedo-induced

416 melting of snow or a warmer climate, could counterbalance ice loss via sublimation and increase

417 the duration of buried ice bodies. Additionally, the presence of large boulders on the surface and

418 within Mullins till will decrease $D_{\text {eff }}$ by effectively decreasing the overall till porosity and

419 increasing tortuosity, as water vapor molecules will be forced to travel a further distance around

420 the obstacles in order to reach the till surface. Kowalewski et al. (2012) found that the presence

421 of a rocky pavement on the till surface decreases annual sublimation by more than $50 \%$. Adding

422 the effects of snow cover, meltwater, and large clasts in our experiment would most likely result

423 in reduced sublimation rates.

424 Salts. The presence of nitratine in Mullins till may play a role in modulating loss of

425 Mullins Glacier ice. Nitratine is highly deliquescent and rapidly absorbs water from the

426 surrounding air (Steiger, 2003). High concentrations of $\mathrm{NaNO}_{3}$, or other deliquescent salt

427 species, may result in water vapor becoming absorbed to salt crystals when the local RH or vapor

428 concentration is high; a process that can be reversed (i.e., efflorescence) when the RH lowers

429 (Hoffman et al., 2004). These processes have been observed in salt-rich soils elsewhere in the

430 Dry Valleys (Dickson et al., 2013) and locally can alter vapor pressure gradients driving

431 diffusion and prevent vapor from diffusing through the entirety of the soil column; efflorescence

432 can also lead to changes in sediment porosity.

433 Long-exposed tills in the MDV develop a vertical salt stratigraphy whereby the

434 concentrations of $\mathrm{Na}$ and $\mathrm{SO}_{4}$ show a peak at a few $\mathrm{cm}$ depth (reflecting the downward

435 percolation of snowmelt and subsequent evaporation) and a general decrease thereafter with 
436 depth (Bao and Marchant, 2006). In addition, sublimation tills, like Mullins till, also show a

437 secondary peak in salt concentration, typically just above the buried-glacier surface (Bao et al.,

438 2008). Salt concentrations at all depths tend to increase over time, and for deposits with long-

439 exposure durations (3-5 Ma) in inland regions of the Dry Valleys peak salt concentrations are

440 typically $1-2 \mathrm{wt} \%$ for $\left[\mathrm{SO}_{4}\right]$ and $<1 \mathrm{wt} \%$ [Na] (Bao and Marchant, 2006). Discrete, low-porosity

441 salt layers would likely result in decreased vapor transport throughout the sediment column, and

442 hence a reduction in sublimation rates.

$444 \quad 7.2$ Comparison with previous studies

445 Multiple studies have examined the sublimation rates of ice in the MDV, including

446 studies of massive ground ice (e.g., Kowalewski et al., 2011; Liu et al., 2015) and ice-cemented

447 ground (e.g., Hagedorn et al., 2007; McKay et al., 1998). Our modeled sublimation rates

448 compare closely to previous studies that examine vapor diffusion under various sediment depths.

449 For example, Liu et al. (2015) found annual sublimation rates between $0.17 \mathrm{~mm}$ and $0.09 \mathrm{~mm}$ for

450 ice in Beacon Valley under $50 \mathrm{~cm}$ of sediment; our model predicts an annual sublimation rate

451 under $50 \mathrm{~cm}$ of till to be $\sim 0.11 \mathrm{~mm}$ under present-day forcing. Similarly, McKay et al. (1998)

452 modeled the annual sublimation rate of a high elevation ice-cemented body in the Asgard Range

453 under $25 \mathrm{~cm}$ of sediment to be 0.4-0.6 mm, and Hagedorn et al. (2007), found the annual

454 sublimation rate of ice-cemented ground under $22 \mathrm{~cm}$ of sediment in Victoria Valley to be 0.22

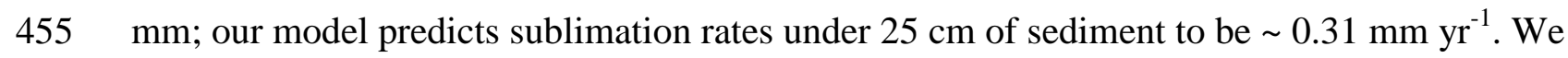

456 expect differences in sublimation rates between studies in the MDV based on the atmospheric

457 forcing of each specific study site (which varies with elevation and distance form the Ross Sea),

458 as well as the modeling approach. Additionally, the sublimation rates from a flat surface, as 
modeled here, would be expected to differ from rates modeled in polygon troughs, or Many of

460 these studies have used effective vapor diffusivity $\left(D_{\text {eff }}\right)$ values less than those determined here

461 (in some cases, less than half), between 1.8 and $3.1 \times 10^{-6} \mathrm{~m}^{2} \mathrm{~s}^{-1}$ (Hagedorn et al., 2007;

462 Kowalewski et al., 2011; Liu et al., 2015). McKay et al. (1998) determined a $D_{\text {eff }}$ of 4.1-5.5 x 10-

$463{ }^{6} \mathrm{~m}^{2} \mathrm{~s}^{-1}$, which is within the range of diffusivities determined in this study. It is possible that

464 some of these disparities could be explained by site-specific differences in lithology and

465 weathering history that would affect the grain-size distribution and other sediment properties.

\section{8. Conclusions}

This study is the first of its kind to use field-site sediment samples and a climate-

469 controlled environmental chamber to examine sublimation rates of buried ice under Antarctic

470 environmental conditions. We determine an effective diffusivity for Fickian vapor transport

471 through Mullins till using experimental measurements of mass loss via ice sublimation beneath

472 varying thicknesses of sediment. Results show $D_{\text {eff }}$ at $-10^{\circ} \mathrm{C}, 40 \% \mathrm{RH}$, and $850 \mathrm{mbar}$ is $(5.2 \pm$

$4730.5) \times 10^{-6} \mathrm{~m}^{2} \mathrm{~s}^{-1}$. We use this value, coupled with micrometeorological data prescribing local

474 environmental conditions on Mullins Glacier, to estimate the sublimation rate of Mullins Glacier

475 ice beneath $1 \mathrm{~cm}$ to $70 \mathrm{~cm}$ of Mullins till, the till thickness overlying the oldest portion of

476 Mullins Glacier. The model results show that ice loss beneath $70 \mathrm{~cm}$ of till is $0.066 \mathrm{~mm} \mathrm{yr}^{-1}$.

477 These experimental and modeling results support recent findings that call for multi-million year

478 preservation of buried glacier ice in the coldest and driest regions of the McMurdo Dry Valleys

479 (e.g., Liu et al., 2015). 
483 Graduate Research Fellowship Program grant awarded to J. Lamp, as well as NSF Grant PLR0944702 awarded to D. Marchant. The authors would like to thank Dr. Joel Sparks for aiding in the experimental setup, as well as Dr. Sean Mackay and Andrew Christ for help in generating the maps and long-term environmental data used in the manuscript. This manuscript was greatly improved by comments from Dr. Chris McKay and two anonymous reviewers.

\section{References}

Bao, H. M., Barnes, J. D., Sharp, Z. D., and Marchant, D. R., 2008, Two chloride sources in soils of the McMurdo Dry Valleys, Antarctica: Journal of Geophysical Research-Atmospheres, v. 113, no. D03301.

Bao, H. M., and Marchant, D. R., 2006, Quantifying sulfate components and their variations in soils of the McMurdo Dry Valleys, Antarctica: Journal of Geophysical ResearchAtmospheres, v. 111, no. D16301.

Campbell, I. B., and Claridge, G. G. C., 2006, Permafrost properties, patterns and processes in the transantarctic mountains region: Permafrost and Periglacial Processes, v. 17, no. 3, p. 215-232.

Chen, N. H., and Othmer, D. F., 1962, New Generalized Equation for Gas Diffusion Coefficient: Journal of Chemical \& Engineering Data, v. 7, no. 1, p. 37-41.

Cullen, D., and Baker, I., 2001, Observation of impurities in ice: Microscopy Research and Technique, v. 55, no. 3, p. 198-207.

Denton, G. H., Sugden, D. E., Marchant, D. R., Hall, B. L., and Wilch, T. I., 1993, East Antarctic Ice Sheet sensitivity to Pliocene climatic change from a Dry Valleys perspective: Geografiska Annaler Series A-Physical Geography, v. 75, no. 4, p. 155-204.

Dickson, J. L., Head, J. W., Levy, J. S., and Marchant, D. R., 2013, Don Juan Pond, Antarctica: Near-surface CaCl2-brine feeding Earth's most saline lake and implications for Mars: Scientific Reports, v. 3.

Fountain, A. G., Nylen, T. H., Monaghan, A., Basagic, H. J., and Bromwich, D., 2010, Snow in the McMurdo Dry Valleys, Antarctica: International Journal of Climatology, v. 30, no. 5, p. 633-642.

Hagedorn, B., Sletten, R. S., and Hallet, B., 2007, Sublimation and ice condensation in hyperarid soils: Modeling results using field data from Victoria Valley, Antarctica: Journal of Geophysical Research-Earth Surface, v. 112, no. F3.

Haynes, W. M., 2015, CRC handbook of chemistry and physics, Chemical Rubber Company handbook of chemistry and physics: Boca Raton, Fla., CRC Press : Taylor \& Francis. Hillel, D., 1998. Environmental soil physics. Academic Press, San Diego, CA. 
Hindmarsh, R. C. A., Van der Wateren, F. M., and Verbers, A. L. L. M., 1998, Sublimation of ice through sediment in Beacon Valley, Antarctica: Geografiska Annaler Series aPhysical Geography, v. 80A, no. 3-4, p. 209-219.

Ho, C. K., and Webb, S. W., 2006, Gas Transport in Porous Media, in Bear, J., ed., Theory and Applications of Transport in Porous Media, Volume 20: Dordrecht, The Netherlands, Springer.

Kossacki, K. J., and Leliwa-Kopystynski, J., 2014, Temperature dependence of the sublimation rate of water ice: Influence of impurities: Icarus, v. 233, p. 101-105.

Kowalewski, D. E., Marchant, D. R., Head, J. W., and Jackson, D. W., 2012, A 2D Model for Characterising First-order Variability in Sublimation of Buried Glacier Ice, Antarctica: Assessing the Influence of Polygon Troughs, Desert Pavements and Shallow Subsurface Salts: Permafrost and Periglacial Processes, v. 23, no. 1, p. 1-14.

Kowalewski, D. E., Marchant, D. R., Levy, J. S., and Head, J. W., 2006, Quantifying low rates of summertime sublimation for buried glacier ice in Beacon Valley, Antarctica: Antarctic Science, v. 18, no. 3, p. 421-428.

Kowalewski, D. E., Marchant, D. R., Swanger, K. M., and Head, J. W., 2011, Modeling vapor diffusion within cold and dry supraglacial tills of Antarctica: Implications for the preservation of ancient ice: Geomorphology, v. 126, no. 1-2, p. 159-173.

Lambert, F., Delmonte, B., Petit, J. R., Bigler, M., Kaufmann, P. R., Hutterli, M. A., Stocker, T. F., Ruth, U., Steffensen, J. P., and Maggi, V., 2008, Dust-climate couplings over the past 800,000 years from the EPICA Dome C ice core: Nature, v. 452, no. 7187, p. 616-619.

Lamp, J. L., Marchant, D. R., Mackay, S. L., and Head, J. W., 2017, Thermal stress weathering and the spalling of Antarctic rocks: Journal of Geophysical Research: Earth Surface, v. 122.

Lewis, A. R., and Ashworth, A. C., 2015, An early to middle Miocene record of ice-sheet and landscape evolution from the Friis Hills, Antarctica: Geological Society of America Bulletin.

Liu, L., Sletten, R. S., Hagedorn, B., Hallet, B., Mckay, C. P., and Stone, J. O., 2015, An enhanced model of the contemporary and long-term (200ka) sublimation of the massive subsurface ice in Beacon Valley, Antarctica: Journal of Geophysical Research-Earth Surface, v. 120, no. 8, p. 1596-1610.

Lowe, P. R., 1977, An Approximating Polynomial for the Computation of Saturation Vapor Pressure: Journal of Applied Meteorology, v. 6, p. 100-103.

Mackay, S. L., and Marchant, D. R., 2016, Dating buried glacier ice using cosmogenic ${ }^{3} \mathrm{He}$ in surface clasts: theory and application to Mullins Glacier, Antarctica: Quaternary Science Reviews, v. 140, p. 175-200.

Mackay, S. L., Marchant, D. R., Lamp, J. L., and Head, J. W., 2014, Cold-based debris-covered glaciers: Evaluating their potential as climate archives through studies of groundpenetrating radar and surface morphology: Journal of Geophysical Research-Earth Surface, v. 119 , no. 11 , p. 2505-2540.

Marchant, D. R., Denton, G. H., and Carl C. Swisher, I., 1993, Miocene-Pliocene-Pleistocene Glacial History of Arena Valley, Quartermain Mountains, Antarctica: Geografiska Annaler Series A-Physical Geography, v. 75, no. 4, p. 269-302.

Marchant, D. R., Denton, G. H., Swisher, C. C., and Potter, N., 1996, Late Cenozoic Antarctic paleoclimate reconstructed from volcanic ashes in the Dry Valleys region of southern Victoria Land: Geological Society of America Bulletin, v. 108, no. 2, p. 181-194. 
Marchant, D. R., Lewis, A. R., Phillips, W. M., Moore, E. J., Souchez, R. A., Denton, G. H., Sugden, D. E., Potter, N., and Landis, G. P., 2002, Formation of patterned ground and sublimation till over Miocene glacier ice in Beacon Valley, southern Victoria Land, Antarctica: Geological Society of America Bulletin, v. 114, no. 6, p. 718-730.

Marchant, D. R., Mackay, S. L., Lamp, J. L., Hayden, A. T., and Head, J. W., 2013, A review of geomorphic processes and landforms in the Dry Valleys of southern Victoria Land: implications for evaluating climate change and ice-sheet stability: Geological Society, London, Special Publications, v. 381.

Marchant, D. R., Phillips, W. M., Schaefer, J. M., Winckler, G., Fastook, J. L., Shean, D. E., Kowalewski, D. E., III, J. W. H., and Lewis, A. R., 2007, Establishing a chronology for the world's oldest glacier ice, 10th International Symposium on Antarctic Earth Sciences (ISAES): Santa Barbara, CA.

Margerison, H. R., Phillips, W. M., Stuart, F. M., and Sugden, D. E., 2005, Cosmogenic He-3 concentrations in ancient flood deposits from the Coombs Hills, northern Dry Valleys, East Antarctica: interpreting exposure ages and erosion rates: Earth and Planetary Science Letters, v. 230, no. 1-2, p. 163-175.

McKay, C. P., 2009, Snow recurrence sets the depth of dry permafrost at high elevations in the McMurdo Dry Valleys of Antarctica: Antarctic Science, v. 21, no. 1, p. 89-94.

McKay, C. P., Mellon, M. T., and Friedmann, E. I., 1998, Soil temperatures and stability of icecemented ground in the McMurdo Dry Valleys, Antarctica: Antarctic Science, v. 10, no. 1, p. 31-38.

Nylen, T. H., Fountain, A. G., Doran, P. T., 2004. Climatology of katabatic winds in the McMurdo dry valleys, southern Victoria Land, Antarctica. J Geophys Res-Atmos 109.

Ohno, H., Igarashi, M., and Hondoh, T., 2005, Salt inclusions in polar ice core: Location and chemical form of water-soluble impurities: Earth and Planetary Science Letters, v. 232, no. 1-2, p. 171-178.

Rignot, E., Hallet, B., and Fountain, A., 2002, Rock glacier surface motion in Beacon Valley, Antarctica, from synthetic-aperture radar interferometry: Geophysical Research Letters, v. 29, no. 12.

Schäfer, J. M., Baur, H., Denton, G. H., Ivy-Ochs, S., Marchant, D. R., Schlüchter, C., and Wieler, R., 2000, The oldest ice on Earth in Beacon Valley, Antarctica: new evidence from surface exposure dating: Earth and Planetary Science Letters, v. 179, no. 1, p. 9199.

Schäfer, J. M., Ivy-Ochs, S., Wieler, R., Leya, J., Baur, H., Denton, G. H., and Schluchter, C., 1999, Cosmogenic noble gas studies in the oldest landscape on earth: surface exposure ages of the Dry Valleys, Antarctica: Earth and Planetary Science Letters, v. 167, no. 3-4, p. 215-226.

Schenk, T., Csatho, B., Ahn, Y., Yoon, T., Shin, S.W., Huh, K.I., 2004. DEM Generation from the Antarctic LiDAR Data: Site Report.

Schorghofer, N., 2009, Buffering of sublimation loss of subsurface ice by percolating snowmelt: a theoretical analysis: Permafrost and Periglacial Processes, v. 20, p. 309-313.

Schorghofer, N., 2005, A physical mechanism for long-term survival of ground ice in Beacon Valley, Antarctica: Geophysical Research Letters, v. 32, no. 19.

Schorghofer, N., and Aharonson, O., 2005, Stability and exchange of subsurface ice on Mars: Journal of Geophysical Research-Planets, v. 110, no. E5. 
Schwertz, F. A., and Brow, J. E., 1951, Diffusivity of Water Vapor in Some Common Gases:

610 The Journal of Chemical Physics, v. 19, no. 5, p. 640-646.

611 Shean, D. E., and Marchant, D. R., 2010, Seismic and GPR surveys of Mullins Glacier, McMurdo Dry Valleys, Antarctica: ice thickness, internal structure and implications for surface ridge formation: Journal of Glaciology, v. 56, no. 195, p. 48-64.

Speirs, J. C., Steinhoff, D. F., McGowan, H. A., Bromwich, D. H., Monaghan, A. J., 2010. Foehn Winds in the McMurdo Dry Valleys, Antarctica: The Origin of Extreme Warming Events: Journal of Climate, v. 23, p. 3577-3598.

Steiger, M., 2003, Salts and Crusts, in Brimblecombe, P., ed., The Effects of Air Pollution on the Built Environment: London, Imperial College Press, p. 133-181.

Sugden, D. E., Marchant, D. R., Potter, N., Souchez, R. A., Denton, G. H., Swisher, C. C., and Tison, J. L., 1995a, Preservation of Miocene Glacier Ice in East Antarctica: Nature, v. 376, no. 6539, p. 412-414.

Sugden, D. E., Denton, G. H., and Marchant, D. R., 1995b, Landscape Evolution of the Dry Valleys, Transantarctic Mountains - Tectonic Implications: Journal of Geophysical Research-Solid Earth, v. 100, no. B6, p. 9949-9967.

Sugden, D. E., Summerfield, M. A., Denton, G. H., Wilch, T. I., McIntosh, W. C., Marchant, D. R., and Rutford, R. H., 1999, Landscape development in the Royal Society Range, southern Victoria Land, Antarctica: stability since the mid-Miocene: Geomorphology, v. 28, no. 3-4, p. 181-200.

Valletta, R. D., Willenbring, J. K., Lewis, A. R., Ashworth, A. C., and Caffee, M., 2015, Extreme decay of meteoric beryllium-10 as a proxy for persistent aridity: Scientific Reports, v. 5.

Yau, A. M., Bender, M. L., Marchant, D. R., and Mackay, S. L., 2015, Geochemical analyses of air from an ancient debris-covered glacier, Antarctica: Quaternary Geochronology, v. 28, p. 29-39. 